\title{
Indicator taxa of benthic diatom communities: a case study in Mediterranean streams
}

\author{
E. Tornés ${ }^{1 *}$, J. Cambra² J. Gomà $^{2}$, M. Leira ${ }^{3}$, R. Ortiz ${ }^{2}$, S. Sabater ${ }^{1}$ \\ ${ }^{1}$ Department of Environmental Sciences and Institute of Aquatic Ecology, Faculty of Sciences, University of Girona, Campus Montilivi,
E-17071 Girona, Spain.
${ }^{2}$ Department of Plant Biology, CEREGA, CERBIV, University of Barcelona, Av. Diagonal 645, 08028 Barcelona, Spain.
${ }^{3}$ Faculty of Sciences, University of A Coruña, Campus da Zapateira, E-15071 A Coruña, Spain.
}

A key issue in the implementation of the Water Framework Directive is the classification of streams and rivers using biological quality parameters and type-specific reference conditions. Four groups of stream types were defined in NE Spain on the basis of 152 diatom samples by means of detrended correspondence analysis and classification techniques. Diatom analysis was restricted to epilithic taxa, and the sites included gradients ranging from near-natural streams to sites with poor ecological quality. The main gradient shows a clear separation of sites in relation to the degree of human influence: polluted streams (mainly located in the lowlands) differ from streams in mountainous areas and in the Pyrenees. A second gradient is related to physiographical features. Headwater streams can be distinguished by their catchment geology. The type-specific diatom taxa for the stream types studied were determined by using indicator species analysis (IndVal). The type-specific taxa from near-natural streams are coincident with the indicator taxa for high ecological status. Human impact reduced the typological heterogeneity of the diatom community composition. Overall, the diatom communities in NE Spain exhibit a regional distribution pattern that closely corresponds with that observed in river systems elsewhere. Physiographical differences are only evident in undisturbed sites, while nutrient enrichment and other human disturbances may mask the regional differences in the distribution of diatom communities.

Keywords: diatom communities, indicator species, multivariate analysis, regional pattern, rivers.

\section{Introduction}

According to the European Union (EU) Water Framework Directive (WFD) (European Commission 2000) the taxonomic composition of benthic diatoms is one of the biological quality elements in the definition of ecological status. Significantly, the determination of ecological status is based on characterizing type-specific reference or near-natural conditions and assessing the ecological quality of streams. This requires the development of a well-established typology and typespecific conditions. Diatoms are known to react sensitively to differences in physical and chemical characteristics of water (Rott et al. 1998, Passy et al. 1999, Winter \& Duthie 2000) and they are abundant in rivers and streams (Round 1981). Since they integrate the environmental effects of water chemistry in addition to the physical and geomorphological characteristics of rivers and lakes, they have been considered among the best limnological indicators (Stoermer \& Smol 1999), and indicator species for different nutritional levels have already been proposed for anthropogenically polluted waters (Sabater \& Admiraal 2005).

\footnotetext{
* Corresponding author : E-mail: elisabet.tornes@udg.es
}

Despite their importance as ecological indicators, large and regional scale knowledge of the structure and function of diatom communities is still scarce (Potapova \& Charles 2002). Diatom communities may differ, both in their composition and relative abundance, because of their ecological affinities and preferences. Consequently, diverse diatom communities occur in natural waters spatially and temporally based on their geological setting, water chemistry and geomorphological conditions (Stevenson \& Pan 1999). Many of these factors depend on climate, geology, topology and other physiographical features, but also on land-use characteristics. Land uses may be similar between ecological regions, and are likely to reduce the weight of physiography on diatom distribution, concealing the natural spatial heterogeneity (Leira \& Sabater 2005). Therefore, it is relevant to understand the broad-scale patterns of diatom distribution in areas of high landscape diversity and a variety of human influences (Potapova \& Charles 2002). Only through a good understanding of the variation in sensitivity and precision of diatom indicator species to environmental conditions among stream types and degrees of human disturbance can we develop and use biological indicators and indices with enough precision and accuracy. 
North East Spain includes diverse physical and ecological regions, in a variety of landscapes ranging from high mountains to Mediterranean-dominated areas, which have been historically modified through irregular human influence. Studies on diatom distribution and autoecological preferences have so far included sparse watersheds (Sabater et al. 1987, Sabater \& Sabater 1988, Sabater \& Roca 1992, Gomà et al. 2004), and none of them has attempted an overall analysis. Under this framework, there is a need to identify typespecific diatom species, since the autoecological requirements are decisive in their use as indicator taxa. Several approaches have been used in ecology to investigate the species assemblages or indicator species that characterize a habitat. Diatom assemblages can be designated by the dominant taxa, but it is important to distinguish the tolerant taxa (occurring in all streams affected by a given disturbance) from those taxa more specific to a given condition. One method used to identify the indicator value of a range of taxa is the indicator value approach (IndVal). This method (Dufrêne \& Legendre 1997) uses a species' degree of specificity and fidelity to an ecological state to define the indicator species as the most characteristic species within each state.

The present work provides an extensive survey of sampling sites, ranging from undisturbed locations to heavily disturbed sites, covering all river types in NE Spain. The objectives of our research were 1) to determine the indicator taxa for different ecological statuses of streams and 2) to identify type-specific taxa for high ecological status. We also discuss how human influences are reflected in the variation in benthic diatom assemblages and type-specific indicator taxa.

\section{Material and methods}

\section{Study area}

The study area was composed of 152 stream and river sites in NE Spain. These sites were selected to cover a wide range of fluvial typologies with different levels of human disturbance. The study sites were mostly located in western areas, with some sites in the hydrographic net of the River Ebro (Fig. 1). The study region has an important spatial heterogeneity determined by its geomorphological and climatic diversity. The sites studied ranged from siliceous high mountain fluvial systems to coastal rivers, passing through calcareous and siliceous Mediterranean fluvial systems. The internal watersheds are strongly influenced by a Mediterranean climate, with marked seasons and interannual variability in rainfall (Gasith \& Resh 1999). These Medi- terranean streams and rivers often flood in autumn and dry up in summer with consequent flow interruption. The shorter rivers (e.g. the Francolí, the Gaià) have their headwaters in middle mountain elevations and flow for a few kilometres to the sea. The larger systems, the Ter and the Llobregat, have their headwaters in the Pyrenees and therefore the upper courses are partially subjected to a snow fed regime. The tributaries of the Ebro watershed also have their headwaters in the Pyrenees, and experience minimum temperatures below $0{ }^{\circ} \mathrm{C}$, annual rainfall of above $1000 \mathrm{~mm}$ and heavy snowfall in winter. The middle and lower parts of the Ebro, the Llobregat and the Ter are subjected to a Mediterranean climate, implying high hydrological variability in these sections. Most of these streams and rivers are regulated and the existence of dams implies striking longitudinal differences in the river (Puig et al. 1987).

The study sites covered the major types of geomorphologic and physiographic conditions (ACA 2003) and encompass the five river types of Catalonia. These five types have been defined in NE Spain in terms of climate, hydrology, geology and relief (Munné \& Prat 2003). Wet mountain rivers (WM) are restricted to the high lands in the northwest (> $600 \mathrm{~m}$ a.s.l.) and encompass most of the Pyrenees ecoregion. This region is characterized by a high annual runoff $(>800 \mathrm{~mm})$ and low mean annual temperatures $\left(<10^{\circ} \mathrm{C}\right)$. Siliceous geology is well represented in this river type (43\%). The Mediterranean mountain rivers (DM) are located at an intermediate altitude (about 300-600 m a.s.1.), and are characterized by a moderate annual air temperature $\left(9-14{ }^{\circ} \mathrm{C}\right)$ and wet climate $\left(>850 \mathrm{~mm}\right.$ year $\left.{ }^{-1}\right)$. The region of dry Mediterranean rivers (DL) is located in the central lowlands and is characterized by dry summers and an annual rainfall below $650 \mathrm{~mm}$, and higher temperatures $\left(14-16{ }^{\circ} \mathrm{C}\right)$. The large watercourses (LW) are also located in the lowlands and comprise those river stretches with high discharge values $\left(>20 \mathrm{~m}^{3} \mathrm{~s}^{-1}\right)$, although they have a moderate annual runoff $\left(0.2-0.4 \mathrm{hm}^{3} \mathrm{~km}^{-2}\right)$ because of the large catchment area drained. Annual precipitation is moderate and the mean annual temperature is about $14{ }^{\circ} \mathrm{C}$. Finally, coastal streams (CS) are located near the Mediterranean coast in the lowlands, and many of them are temporary or ephemeral streams, characterized by their small drainage area $\left(<250 \mathrm{~km}^{2}\right)$ and intermittent flow regime (>120 dry days per year).

\section{Sampling and species identification}

Diatom sampling was conducted during summer (July-August) 2002 and spring (May-June) 2003. 


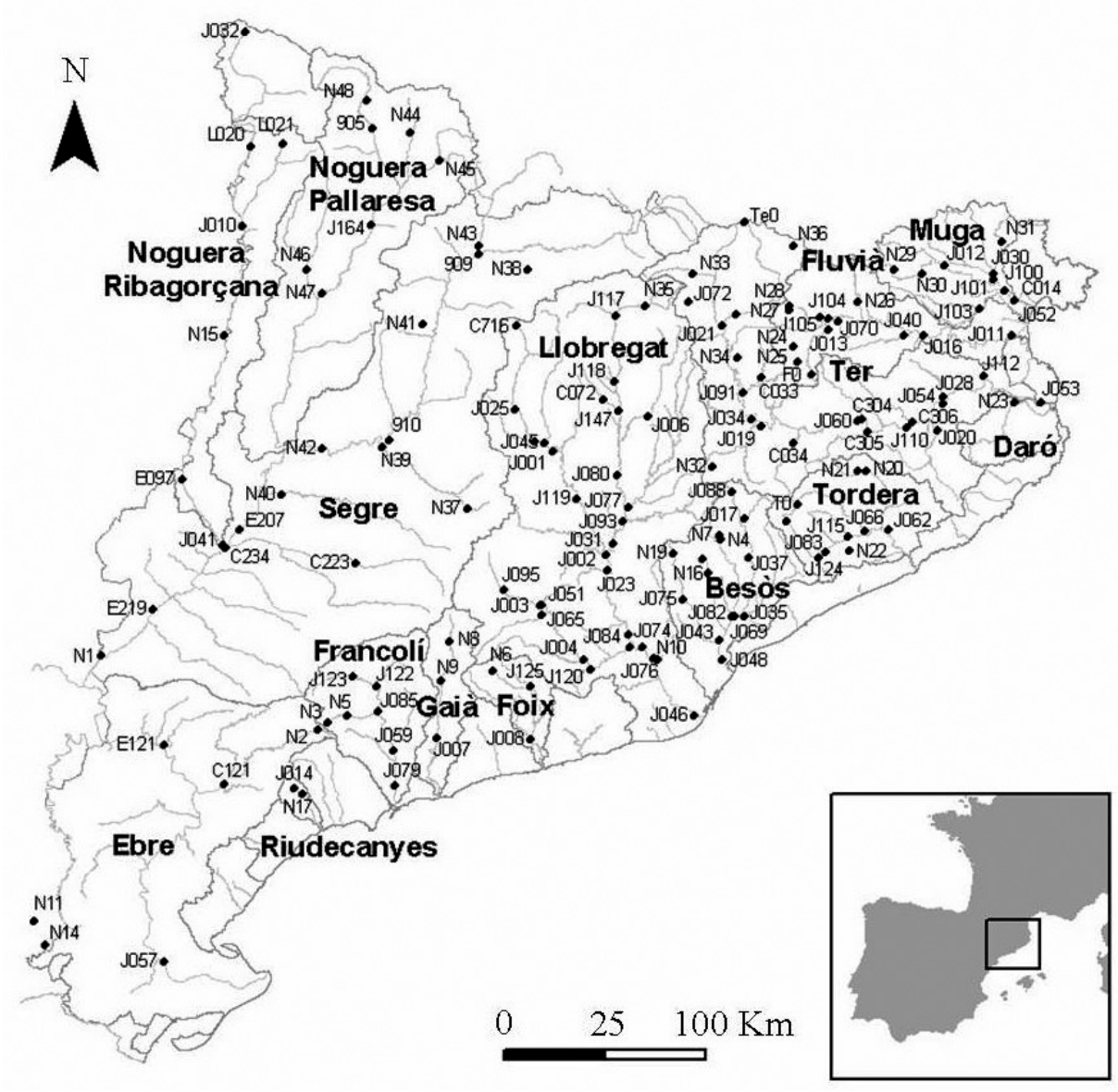

Fig.1. Map of the study area and location of the sampling sites.

Sampling and counting followed CEN standards $(2000,2001)$. At least five stones were randomly collected from the stream bottom in riffle sections. The substrata were scraped with a toothbrush or a knife to detach the algal communities to a final area of 2-10 $\mathrm{cm}^{2}$. The use of a toothbrush or a knife depended on the nature of the substrata sampled: if the substratum was softer, a toothbrush was used; in the case of harder substrata, the knife proved more efficient. Algal samples were preserved in formaldehyde $4 \%$ until analysis. The available environmental data for the sampling sites included both water chemistry and physical characteristics. The physical data collected in the field were dissolved oxygen, water temperature, conductivity and $\mathrm{pH}$. Qualitative observations were also obtained for water transparency, light and the river habitat. Chemical data analyses were provided by the Catalan Water Agency (ACA). The altitude of the sites was derived from the Digital Elevation Model (DEM, $30 \mathrm{~m}$ x $30 \mathrm{~m}$ ) of the Institute of Catalan Cartography (ICC, www.icc.es) using ESRI ArcGIS ${ }^{\circledR}$.

Diatom frustules were cleaned from the organic material using sulphuric acid, dichromate potassium and hydrogen peroxide, or, alternatively, hot hydrogen peroxide. Frustules were mounted on permanent slides using Naphrax (r.i. 1.74). At least 400 valves were counted on each slide by performing random transects under light microscopy using Nomarski differential interference contrast optics at a magnification of $1000 \mathrm{x}$. Taxa were identified mainly according to Krammer and Lange-Bertalot (1991-1997) and Lange-Bertalot (2001).

\section{Data analysis}

Multivariate data analyses were performed on the diatom dataset to explore the main gradients of com- 
munity variation and to detect and visualize similarities in the diatom samples. The major patterns of variation in the species composition data were described using a detrended correspondence analysis (DCA). DCA is an indirect gradient technique which assumes a unimodal response of species to their environment. Detrending by segments was undertaken using the CANOCO version 4.5 (ter Braak \& Šmilauer 2002). Since the sampling data were distributed between two different seasons and years, time was considered as a categorical co-variable in order to avoid the effect of seasonal differences between the two study periods.

Given that DCA is a gradient analysis technique, the groups it outlined were not strictly followed. Therefore, a cluster analysis was performed to determine whether the interpretation of the DCA could result in the formation of different groups of sites. Sorensen's similarity coefficient was measured on square-root transformed abundance data, and "flexible beta" was selected as the linkage method. "Flexible beta" was set to -0.25 (Dufrêne \& Legendre 1997). The cluster analysis was run with PC-Ord 4.2 (McCune \& Mefford 1999). The statistical significance of between-group differences was tested using the multi-response permutation procedure (MRPP). MRPP is a non-parametric procedure that tests the hypothesis of no differences in assemblage structure among groups (Zimmerman et al. 1985). Sorensen's coefficient was also used as the distance measure. MRPP has the advantage of not requiring assumptions (such as multivariate normality and homogeneity of variances) that are seldom met with ecological community data. MRPP was also implemented using the program PC-Ord 4.2.

The Water Framework Directive assumes the denomination of type-specific taxa. Therefore, it is of the utmost importance to detect and describe the value of different species as indicators of type-specific environmental conditions. The indicator value method (IndVal; Dufrêne \& Legendre 1997) was then used to identify the indicator species of these groups of sites. IndVal is a simple and useful method to identify indicator species and species assemblages characterizing groups of samples (Dufrêne \& Legendre 1997). The originality of this method lies in the way it combines information on the specificity and the fidelity of occurrence of a species in a particular group. It produces indicator values for each species in each group expressed as the product of the specificity and fidelity. Therefore, indicator species are defined as the most characteristic species of each group. The method derives indicators from any site classification. Taxa which were mostly observed in only one type of stream were nominated as type- specific. The statistical significance of the species indicator values is evaluated using a randomization procedure. The indicator value of a species $i$ is the largest value of IndVal ${ }_{i j}$ observed among all groups $j$. The indicator value is at its maximum when all individuals of a species are found in a single group of sites (high specificity) and when the species occurs in all sites of that group (high fidelity) (Dufrêne \& Legendre 1997).

Only those taxa occurring in at least one site with an abundance of more than $1 \%$ during each of the sampling seasons were included in the analyses to minimize the influence of rare taxa. All analyses were carried out with square root transformed abundance data, except for the IndVal calculations which uses untransformed abundances.

\section{Results}

\section{Ordination}

The DCA accounted for a relatively low percentage of explained variance. This is usual in noisy data sets which contain a large number of samples and taxa with zero values. Nevertheless, DCA effectively identified coherent ecological signals on the first two axes of our dataset. The first DCA axis ( $15.5 \%$ of the variance) summarized the distribution of the diatom communities throughout the conductivity and nutrient gradient, which arranged the sites from the headwaters to the lowlands. The most polluted sites were clustered on the left side of the axis (Fig. 2) and corresponded to low elevation sites located in densely populated, highly industrialized or agricultural areas. Diatom taxa showing maximum abundance in these samples were Nitzschia desertorum, Navicula saprophila, Nitzschia capitellata, Nitzschia frustulum, Navicula subminuscula, Nitzschia palea, Navicula veneta and Cyclotella meneghiniana. Sites on the right side of the axis corresponded to communities in oligotrophic headwaters. Diatom taxa abundant in these samples were Cymbella delicatula, Achnanthes biasolettiana, Fragilaria arcus, Cymbella microcephala, Cymbella affinis and Gomphonema pumilum.

The second DCA axis accounted for $6.7 \%$ of the variance. The main part of the near-natural or reference study sites were distributed along this axis. Sites with lower water temperatures and poorly mineralized waters were grouped together and apart from samples with higher temperatures and mineral content. Sites in the upper part of the diagram were in cold, siliceous, high mountain headwaters of low mineralization. These were associated with Fragilaria capucina var. 

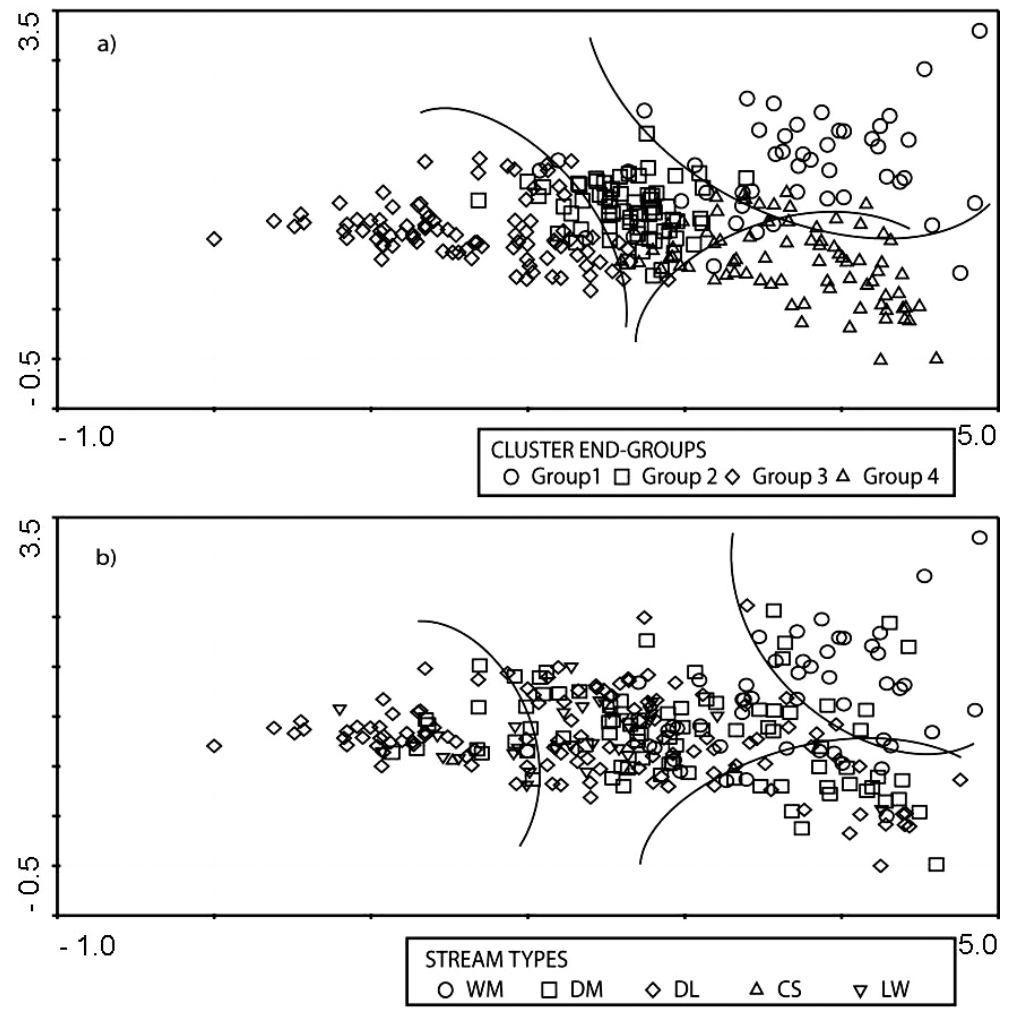

Fig.2. Detrended correspondence analysis (DCA) of diatom communities in rivers of NE Spain in the ordination space of the first and second axis; a) DCA ordination of diatom assemblage samples classified by cluster groups, b) DCA ordination of diatom samples classified by river typology. Taxa codes correspond to those of Table 1 .

rumpens, Fragilaria arcus and Cymbella sinuata. Sites in the lower part of the diagram were in mineralized waters of calcareous mid-mountain headwaters, where Cymbella microcephala, Cymbella delicatula and Cymbella affinis were characteristic.

\section{Diatom groups and type-specific taxa}

After ordering the diatom communities by DCA as outlined above, a cluster analysis was performed. This classification analysis produced 4 groups of sites and confirmed the indications of the DCA (Table 1 and Fig. 3). A MRPP indicated significant differences between the identified groups $(\mathrm{p}<0.0001)$. The main physical and water quality characteristics of the four groups of sites are indicated in Table 2.

Cluster group 1 (47 cases) included unpolluted and siliceous high mountain headwater sites mostly in streams of the WM region. A second cluster group (67 cases) consisted of sites in moderately enriched and mineralized waters. This group included most of the river types, with overlapping of nearly natural and slightly impacted sites. Cluster 3 accounted for sites in highly polluted lowland streams (92 cases), mostly in the dry Mediterranean region. Finally, the fourth cluster group (76 cases) consisted of mineralized and midaltitude mountain headwaters. Most of the streams in this group were located in the DM region.

Only eleven species were recorded as having high IndVals (> 50\%) and could therefore be considered as good indicator species (Table 1). Nearly all site groups had species with high IndVals (> 50\%). Species with higher IndVals were mostly characteristic in lowland, highly polluted rivers, as well as in mineralized midmountain headwaters. Although few species emerged as indicator species with high IndVals $(>50 \%)$ in unpolluted siliceous streams, those with low IndVals showed a high frequency of occurrence (high fidelity) in this group. 
Table 1. Indicator values (IndVal) results for the most important taxa in each stream group. Significance of each species as a type-specific indicator was assessed by means of Monte Carlo tests based on 999 permutations ( $\mathrm{P}$ value $<0.001$ ). Fidelity (F) and specificity (S) values are also shown.

\begin{tabular}{|c|c|c|c|c|c|c|c|c|c|c|c|c|c|}
\hline & \multirow[t]{2}{*}{ Code } & \multicolumn{3}{|c|}{ Group 1} & \multicolumn{3}{|c|}{ Group 2} & \multicolumn{3}{|c|}{ Group 3} & \multicolumn{3}{|c|}{ Group 4} \\
\hline & & $\mathrm{F}$ & $\mathrm{S}$ & IndVal & $\mathrm{F}$ & $\mathrm{S}$ & IndVal & $\mathrm{F}$ & $\mathrm{S}$ & IndVal & $\mathrm{F}$ & $\mathrm{S}$ & IndVal \\
\hline Achnanthes biasolettiana Grunow & ABIA & 75 & 79 & 59 & 3 & 30 & 1 & 0 & 8 & 0 & 21 & 75 & 16 \\
\hline Achnanthes minutissima Kützing & AMIN & 26 & 91 & 24 & 12 & 99 & 12 & 3 & 62 & 2 & 59 & 100 & 59 \\
\hline Amphora inariensis Krammer & AINA & 4 & 15 & 1 & 65 & 58 & 38 & 2 & 5 & 0 & 29 & 21 & 6 \\
\hline Cymbella affinis Kützing & CAFF & 15 & 49 & 8 & 4 & 30 & 1 & 3 & 12 & 0 & 78 & 88 & 68 \\
\hline Cymbella microcephala Grunow & CMIC & 3 & 30 & 1 & 2 & 15 & 0 & 1 & 12 & 0 & 94 & 82 & 77 \\
\hline $\begin{array}{l}\text { Cymbella minuta Hilse } \\
\text { ex Rabenhorst }\end{array}$ & CMIN & 41 & 79 & 32 & 33 & 75 & 25 & 0 & 7 & 0 & 26 & 62 & 16 \\
\hline Cymbella sinuata Gregory & CSIN & 54 & 57 & 31 & 41 & 48 & 20 & 0 & 4 & 0 & 5 & 21 & 1 \\
\hline Denticula tenuis Kützing & DTEN & 18 & 32 & 6 & 2 & 7 & 0 & 0 & 1 & 0 & 79 & 67 & 53 \\
\hline $\begin{array}{l}\text { Diatoma mesodon (Ehrenberg) } \\
\text { Kützing }\end{array}$ & DMES & 96 & 36 & 35 & 3 & 6 & 0 & 1 & 1 & 0 & 1 & 3 & 0 \\
\hline Diatoma moniliformis Kützing & DMON & 4 & 15 & 1 & 6 & 18 & 1 & 4 & 13 & 1 & 86 & 55 & 47 \\
\hline $\begin{array}{l}\text { Gomphonema pumilum (Grunow) } \\
\text { Reichardt \& Lange-Bertalot }\end{array}$ & GPUM & 85 & 38 & 33 & 1 & 10 & 0 & 1 & 9 & 0 & 12 & 46 & 5 \\
\hline Navicula capitatoradiata Germain & NCPR & 7 & 21 & 1 & 80 & 51 & 40 & 5 & 18 & 1 & 8 & 22 & 2 \\
\hline Navicula gregaria Donkin & NGRE & 3 & 15 & 0 & 62 & 78 & 48 & 30 & 60 & 18 & 5 & 29 & 2 \\
\hline $\begin{array}{l}\text { Navicula saprophila Lange-Bertalot } \\
\& \text { Bonik }\end{array}$ & NSAP & 2 & 21 & 0 & 28 & 73 & 21 & 68 & 85 & 58 & 2 & 20 & 0 \\
\hline Navicula subminuscula Manguin & NSBM & 0 & 4 & 0 & 3 & 33 & 1 & 94 & 66 & 62 & 3 & 13 & 0 \\
\hline Navicula veneta Kützing & NVEN & 13 & 13 & 2 & 20 & 66 & 13 & 62 & 85 & 52 & 5 & 32 & 2 \\
\hline Nitzschia fonticola Grunow & NFON & 26 & 55 & 14 & 56 & 85 & 48 & 4 & 35 & 2 & 14 & 54 & 7 \\
\hline $\begin{array}{l}\text { Nitzschia frustulum (Kützing) } \\
\text { Grunow }\end{array}$ & NIFR & 1 & 11 & 0 & 5 & 33 & 2 & 92 & 67 & 62 & 3 & 25 & 1 \\
\hline Nitzschia inconspicua Grunow & NINC & 4 & 23 & 1 & 48 & 85 & 41 & 44 & 50 & 22 & 4 & 22 & 1 \\
\hline Nitzschia palea (Kützing) W. Smith & NPAL & 5 & 34 & 2 & 17 & 67 & 11 & 75 & 78 & 59 & 3 & 34 & 1 \\
\hline
\end{tabular}

Only Achnanthes biasolettiana showed a high IndVal $(59 \%)$ in the unpolluted (Table 2) siliceous upland streams (Group 1). Diatoma mesodon, Gomphonema pumilum, Cymbella minuta, Fragilaria arcus and Cymbella sinuata showed a perfect indication between 25 $35 \%$. The species with the highest indicator value in Group 2 (Nitzschia fonticola, Navicula gregaria and Nitzschia inconspicua) showed a certain degree of preference for this particular environmental condition (i.e. high specificity), although they were also present across other stream types. In Group 3 only six taxa had a value index $>50 \%$. These were Nitzschia frustulum, Navicula saprophila, Nitzschia palea, Navicula submuralis, Navicula veneta and Navicula capitellata, and they were therefore characteristic of lowland highly polluted sites with high mean phosphate and nitrate concentrations (Table 2). Indicator species (IndVal > $50 \%$ ) of cluster Group 4 were Cymbella microcephala, Cymbella affinis, Achnanthes minutissima and Denticula tenuis. These were indicator taxa from mineralized mid-mountain headwaters (Table 2).

\section{Discussion}

The diatom communities' composition and the characteristic species of each group of sites in NE Spain closely corresponded with those observed in other geographical areas (Potapova \& Charles 2002, Martínez de Fabricius et al. 2003, Soininen et al. 2004). Benthic diatom assemblages are controlled by multiple factors reflecting land use and site-specific conditions at various temporal and spatial scales (DeNicola et al. 2004, 


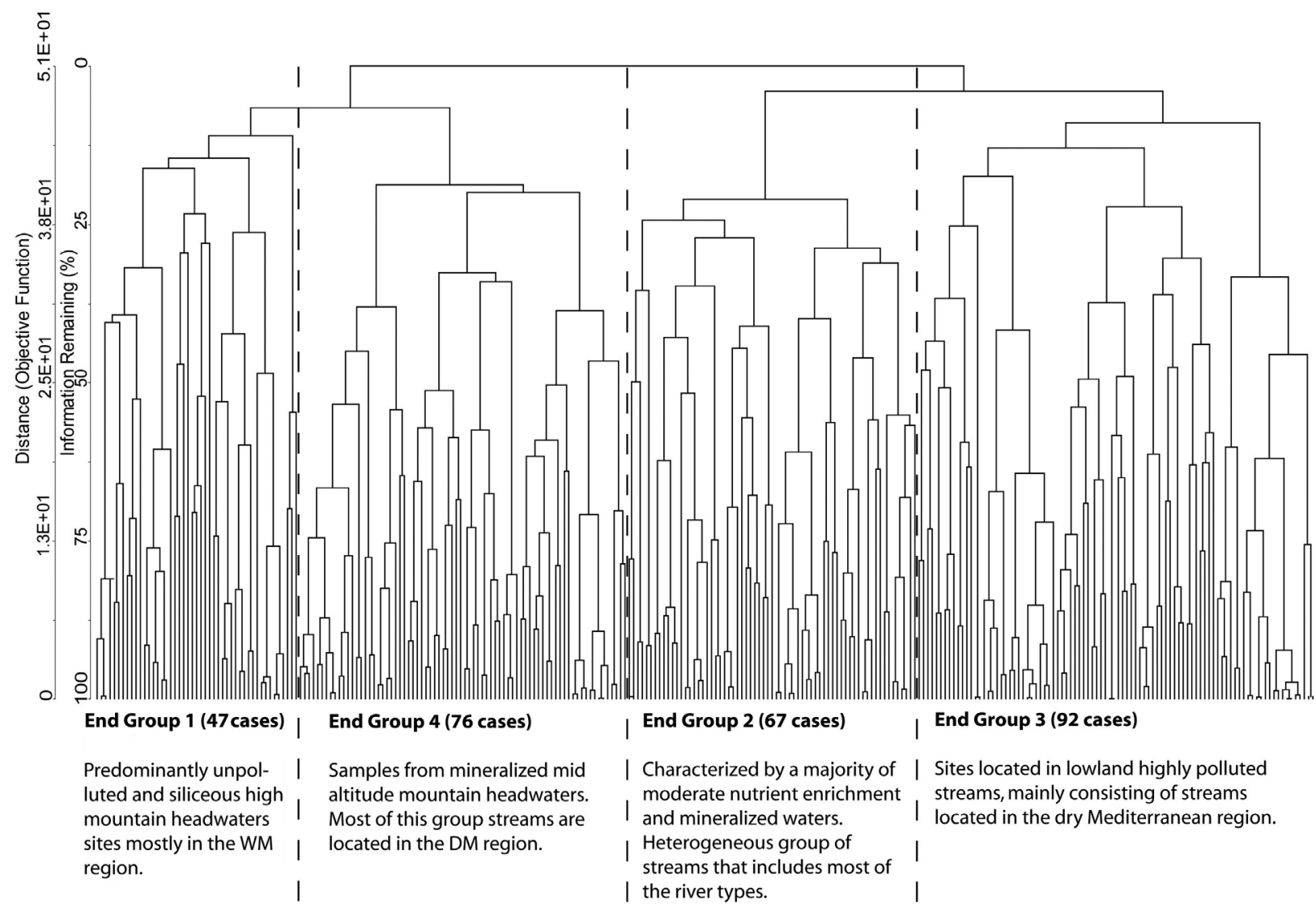

Fig.3. Cluster dendogram of the sampling sites. The four groups, with the number of sampling sites per group indicated in brackets, are identified and characterized.

Pan et al. 2004). Diatom distribution is sensitive not only to the biogeochemical characteristics of the waters (Aboal et al. 1996, Potapova 1996) and their nutrient content (Rott 1995, Licursi \& Gómez 2002), but also to water velocity and substratum type (Passy et al. 1999, Martínez de Fabricius et al. 2003). The respective relevance of water quality variation and physiographic processes in rivers in a precise geographical area are expressed in a complex gradient, in which the interaction between local and broader-scale factors determines the composition of diatom assemblages (Cushing et al. 1983, Molloy 1992, Steinman et al. 1992, Robinson et al. 1994, Leland 1995). Our study shows the existence of a strong spatial component, with distinctly different communities among river typologies. As a consequence, the indicator taxa for the near-natural streams proved to be type-specific.
Achnanthes biasolettiana was type-specific for high altitude, siliceous streams and was not observed in highly impacted streams. This taxon is characteristic of upstream sites with low human impact (Martínez de Fabricius et al. 2003, Soininen et al. 2004). Gomphonema pumilum and Cymbella minuta were also included in this group. The resulting species assemblage is widely spread in headwaters characterized by low nutrient conditions (Lange-Bertalot 1980, Kelly 2002, Martínez de Fabricius et al. 2003).

In oligotrophic and mineralized headwaters the typespecific indicator taxa were Achnanthes minutissima, Cymbella microcephala, Cymbella affinis and Denticula tenuis. Several Cymbella taxa and Achnanthes minutissima are dominant in the diatom communities of Pyrenean calcareous springs (Sabater and Roca 1992). Cymbella showed the highest affinity towards calcium 
Table 2. Statistical description for the environmental variables in each cluster group.

\begin{tabular}{|c|c|c|c|c|c|c|c|}
\hline & & $\mathrm{N}$ & Mean & $\begin{array}{c}\text { Standard } \\
\text { Deviation }\end{array}$ & $\begin{array}{c}\text { Standard } \\
\text { Error }\end{array}$ & Minimum & Maximum \\
\hline \multirow{5}{*}{$\begin{array}{l}\text { Conductivity } \\
\left(\mu \mathrm{S} \mathrm{cm} \mathrm{cm}^{-1}\right)\end{array}$} & 1 & 45 & 310.88 & 500.58 & 74.62 & 19.20 & 3320.00 \\
\hline & 2 & 67 & 764.04 & 1317.22 & 160.92 & 105.40 & 10770.00 \\
\hline & 3 & 86 & 1474.05 & 1550.72 & 167.22 & 284.00 & 14184.00 \\
\hline & 4 & 67 & 577.76 & 553.10 & 67.57 & 45.90 & 3410.00 \\
\hline & Total & 265 & 870.41 & 1234.07 & 75.81 & 19.20 & 14184.00 \\
\hline \multirow{5}{*}{$\begin{array}{l}\text { Nitrate } \\
\left(\mathrm{mg} \mathrm{NO}_{3} \mathrm{~L}^{-1}\right)\end{array}$} & 1 & 35 & 2.26 & 4.11 & 0.69 & 0.05 & 22.00 \\
\hline & 2 & 53 & 10.78 & 12.91 & 1.77 & 0.05 & 89.00 \\
\hline & 3 & 81 & 13.21 & 12.80 & 1.42 & 0.05 & 71.50 \\
\hline & 4 & 47 & 6.38 & 12.58 & 1.84 & 0.05 & 69.63 \\
\hline & Total & 216 & 9.35 & 12.41 & 0.84 & 0.05 & 89.00 \\
\hline \multirow{5}{*}{$\begin{array}{l}\text { Phosphate } \\
\left(\mathrm{mg} \mathrm{P}_{2} \mathrm{O}_{5} \mathrm{~L}^{-1}\right)\end{array}$} & 1 & 35 & 0.19 & 0.38 & 0.06 & 0.01 & 1.80 \\
\hline & 2 & 53 & 0.64 & 1.86 & 0.25 & 0.01 & 12.30 \\
\hline & 3 & 81 & 1.49 & 2.54 & 0.28 & 0.01 & 16.50 \\
\hline & 4 & 47 & 0.23 & 0.47 & 0.07 & 0.01 & 2.87 \\
\hline & Total & 216 & 0.80 & 1.90 & 0.13 & 0.01 & 16.50 \\
\hline \multirow{5}{*}{$\begin{array}{l}\text { TOC } \\
\left(\mathrm{mg} \mathrm{C} \mathrm{L}^{-1}\right)\end{array}$} & 1 & 32 & 1.99 & 2.95 & 0.52 & 0.05 & 17.07 \\
\hline & 2 & 52 & 2.62 & 1.62 & 0.22 & 0.50 & 8.10 \\
\hline & 3 & 80 & 5.51 & 5.90 & 0.66 & 0.05 & 44.70 \\
\hline & 4 & 46 & 1.89 & 1.63 & 0.24 & 0.05 & 10.75 \\
\hline & Total & 210 & 3.46 & 4.28 & 0.30 & 0.05 & 44.70 \\
\hline \multirow{5}{*}{$\begin{array}{l}\text { Water } \\
\text { temperature } \\
\left({ }^{\circ} \mathrm{C}\right)\end{array}$} & 1 & 42 & 14.85 & 3.68 & 0.57 & 8.00 & 22.00 \\
\hline & 2 & 67 & 18.04 & 3.53 & 0.43 & 11.10 & 29.00 \\
\hline & 3 & 85 & 19.67 & 3.31 & 0.36 & 11.00 & 26.80 \\
\hline & 4 & 67 & 16.40 & 3.73 & 0.46 & 8.00 & 24.90 \\
\hline & Total & 261 & 17.64 & 3.93 & 0.24 & 8.00 & 29.00 \\
\hline \multirow{5}{*}{$\begin{array}{l}\text { Altitude } \\
\text { (m) }\end{array}$} & 1 & 47 & 844 & 519 & 76 & 82 & 2241 \\
\hline & 2 & 67 & 245 & 247 & 30 & 0 & 937 \\
\hline & 3 & 92 & 189 & 216 & 23 & 1 & 1746 \\
\hline & 4 & 75 & 509 & 287 & 33 & 9 & 1746 \\
\hline & Total & 281 & 397 & 390 & 23 & 0 & 2241 \\
\hline
\end{tabular}

in a dataset collected from sites throughout the USA (Potapova \& Charles 2003). However, the abundance of Achnanthes minutissima in headwaters is related to it being an early colonizer (Kelly 2002, Martínez de Fabricius et al. 2003) and favoured by the high water velocities in headwater streams.

Taxa such as Navicula saprophila, Navicula subminuscula, Nitzschia capitellata, Nitzschia palea, Navicula veneta and Nitzschia frustulum were type-specific for river sections affected by intensive agricultural and industrial activities. These taxa have been described as highly tolerant and resistant to organic pollution (Vidal \& Gentili 2000, Fawzi et al. 2002, Soininen 2002, John 2004, Rakowska 2004). Low elevation stretches support high irradiances, slow-moving waters and naturally high nutrient concentrations. The diatom taxa characteristic in these situations, such as Navicula gregaria, Nitzschia fonticola and Nitzschia inconspicua, are widespread in lowland rivers (Martínez de Fabricius et al. 2003). 
Nutrient-enrichment and human disturbances have an overriding effect on local and large-scale factors, which are likely to reduce the regional differences (Gasse et al. 1983, Sabater \& Roca 1992, Potapova \& Charles 2003). An obvious consequence is that differences in diatom assemblage composition are more evident among relatively undisturbed sites than among sites severely affected by nutrient enrichment. In our dataset, sites in mid and low altitude areas with intensive agriculture and industry showed the largest overlap between nutrient-enrichment and physiographic factors (Leira \& Sabater 2005). Accordingly, diatom species composition in the two groups of polluted sites showed the highest similarities to those sites subjected to human impact elsewhere, regardless of their regional context. In streams with moderately polluted and mineralized waters, indicator values for the most characteristic species were all $<50 \%$ of perfect indication, implying that these taxa can be considered as sufficiently uncharacteristic. This might be, to a certain extent, a consequence of the overlapping conditions between near natural and impacted streams. Taxa characteristic of a particular habitat (i.e. high specificity and high fidelity) have a high indicator value. However, species showing another combination of specificity and fidelity might be useful indicators and are relatively resilient to changes. Some species with the highest indicator values (e.g. Nitzschia fonticola, Navicula gregaria and Nitzschia inconspicua) show a certain degree of preference for a particular environmental condition (i.e. high specificity), although they are also present across other stream types. Highly specific taxa are restricted to a single state and, consequently, these species might be regarded as sufficiently indicative of those sites with moderate nutrient enrichment. Under changing environmental conditions, species are more likely to decline or increase in abundance (i.e. fidelity), indicating mixed conditions or demonstrating a shift between different states.

One of the strong inferences that may be drawn from the present results is that disturbances lead to the homogenization of the diatom community composition over wide areas. Classification analysis grouped together streams with similar water chemistry, independently of their regional differences. River typology corresponded to diatom assemblage classification among the least impacted sites when biota is regulated by regional factors, and where characteristic taxa indicated specific autoecological requirements. Interestingly, some taxa for highly impacted streams proved to be type-specific because they were mostly located in the dry Mediterranean climate region, thus showing a narrower geographical and ecological distribution. Given the strong downstream pollution gradient, this might suggest that anthropogenic impacts were not capable of overriding the regional, large-scale patterns in community structure.

\section{Conclusions}

The information value of indicators depends largely on how they are developed and calibrated, and more precisely on how well the autoecological requirements of those taxa are quantified. A key issue in developing indicator taxa is understanding the linkages between regional factors and diatom distribution. One conclusion derived from our study is that the use of diatom indices as an ecological tool (Descy 1979, Cemagref 1982) needs to take account of the different autoecological characteristics of the diatom taxa in different regions, and be adapted if it is to provide a reliable diagnosis of specific river systems. One of the main objectives of the WFD is to achieve a good ecological status for all European aquatic ecosystems by 2015 . The WFD provides a framework for the protection of inland surface waters, transitional waters, coastal waters and groundwater. Our findings support the characterization of river types through two classification systems (A and B) (Annex II of the WFD). The main purpose of typology is to enable type-specific conditions to be defined and to apportion study units. If the distribution of a diatom is limited primarily by regional characteristics, it should not be applied over wide areas so as to accurately discriminate between natural and human-induced changes.

\section{Acknowledgements}

This study was funded by the Agència Catalana de l'Aigua. Additional funding was obtained from the CICYT CGL2005-06739$\mathrm{CO} 2 /$ BOS of the Spanish Science Ministry and the European Project MODELKEY (contract number 511237-2). Elisabet Tornés was recipient of a fellowship (FPI) by the Spanish Science Ministry.

\section{References}

Aboal M., Puig M.A. \& Soler G. 1996. - Diatom assemblages in some Mediterranean temporary streams in southeastern Spain. Arch. Hydrobiol., 136, 509-527.

ACA. 2003. - Viability analysis and proposal of phytobenthonic indicators for the water quality in catalan fluvial systems (Anàlisi de la viabilitat i proposta d'indicadors fitobentònics de la qualitat de l'aigua per als cursos fluvials de Catalunya). Report of the Agència Catalana de l'Aigua, Barcelona.

Cemagref. 1982. - Study of the quantitative biological methods for assessing water quality (Étude des méthodes biologiques d'appréciation quantitative de la qualité des eaux). Rapport Division qualité des eaux Cemagef Lyon. Agence de l'Eau Rhône-Méditerranée-Corse, Lyon. 
CEN. European Committee for Standardization. 2000. - Water quality. Guidance standard for the routine sampling and pre-treatment of benthic diatoms from rivers for water quality assessment. European Standard. prEN 13946.

CEN. European Committee for Standardization. 2001. - Water quality. Guidance standard for the identification and enumeration of benthic diatom samples from rivers and their interpretation. European Standard. TC 230 WI 00230164

Cushing C.E., Cummins K.W., Minshall G.W. \& Vannote R.L. 1983. - Periphyton, chlorophyll $a$, and diatoms of the Middle Fork of the Salmon River, Idaho. Holarctic Ecol., 6, 221-227.

DeNicola D.M., Eyto E.D., Wemaere A. \& Irvine K. 2004. - Using epilithic algal communities to assess trophic staus in Irish lakes. $J$. Phycol., 40, 481-495.

Descy J.P. 1979. - A new approach to water quality estimation using diatoms. Nova Hedwigia, 64, 305-323.

Dufrêne M. \& Legendre P. 1997. - Species assemblages and indicator species: the need for a flexible asymmetrical approach. Ecol. Monogr., 67, 345-366.

European Commission. 2000. - Directive 2000/60/EC of The European Parliament and of the Council-Establishing a Framework for Community Action in the Field of Water Policy. Brussels, Belgium, 23 October 2000.

Fawzi B., Loudiki M., Oubraim S., Sabour B. \& Chlaida M. 2002. Impact of wastewater effluent on the diatom assemblages structures of a brackish small stream: Oued Hassar (Morocco). Limnologica, 32, 54-65.

Gasith A. \& Resh V.H. 1999. - Streams in Mediterranean climate regions: abiotic influences and biotic responses to predictable seasonal events. Annu. Rev. Ecol. Syst., 30, 51-81.

Gasse F., Talling J.F. \& Kilham P. 1983. - Diatom assemblages in East Africa: classification, distribution and ecology. Rev. Hydrobiol. Trop., 16, 3-34.

Gomà J., Ortiz R., Cambra J. \& Ector L. 2004. - Water quality evaluation in catalonian mediterranean rivers using epilithic diatoms as bioindicatos. Vie Milieu, 54, 81-90.

John J. 2004. - Diatom assemblages as indicators of wastewater discharge in a temporary stream in Western Australia. Pages 129-145 in Proceedings of the 17th International Diatom Symposium 2002. Poulin M. (ed.)

Kelly M.G. 2002. - Role of benthic diatoms in the implementation of the Urban Wastewater Treatment Directive in the River Wear, North-East England. J. Appl. Phycol., 14, 9-18.

Krammer K. \& Lange-Bertalot H. 1991-1997. - Bacillariophyceae, 2 (1-4). In Süsswasserflora von Mitteleuropa. Ettl H., Gerloff J., Heynig H. \& Mollenhauer D. (eds.). Fischer, Stuttgart.

Lange-Bertalot H. 1980. - Ein beitrag zur Revision der Gattungen Rhoicosphenia Grun., Gomphonema C. Ag., Gomphoneis Cl. Bot. Not., 133, 585-594.

Lange-Bertalot H. 2001. - Navicula sensu stricto, 10 genera separated from Navicula sensu lato, Frustulia, 2. In Diatoms of Europe. Lange-Bertalot H. (ed.). Gantner Verlag, Ruggell, 526 p.

Leira M. \& Sabater S. 2005. - Diatom assemblages distribution in catalan rivers, NE Spain, in relation to chemical and physiographical factors. Wat. Res., 39, 73-82.

Leland H.V. 1995. - Distribution of phytobenthos in the Yakima River basin, Washington, in relation to geology, land use, and other environmental factors. Can. J. Fish. Aquat. Sci., 52, 1108-1129.

Licursi M. \& Gómez N. 2002. - Benthic diatoms and some environmental conditions in three lowland streams. Ann. Limnol. - Int. J. Lim., 38, 109-118.

Martínez de Fabricius A.L., Maidana N., Gómez N. \& Sabater S. 2003. - Distribution patterns of benthic diatoms in a Pampean river exposed to seasonal floods: the Cuarto River (Argentina). Biodiv. Conserv., 12, 2443-2454.
McCune B. \& Mefford M.J. 1999. - PC-ORD. Multivariate analysis of ecological data, Version 4.20. MjM Software, Gleneden Beach, Oregon.

Molloy J.M. 1992. - Diatom communities along stream longitudinal gradients. Freshwat. Biol., 28, 59-69.

Munné A. \& Prat N. 2004. - Defining river types in a Mediterranean Area: a methodology for the implementation of the EU Water Framework Directive. Environ. Manag., 34, 711-729.

Pan Y., Herlihy A., Kaufmann M., Wigington J., van Sickle J. \& Moser T. 2004. - Linkages among land-use, water quality, physical habitat conditions and lotic diatom assemblages: a multi-spatial scale assessment. Hydrobiologia, 515, 59-73.

Passy S.I., Pan Y.D. \& Lowe R.L. 1999. - Ecology of the major periphytic diatom communities from the Mesta River, Bulgaria. Internat. Rev. Hydrobiol., 84, 129-174.

Potapova M. 1996. - Epilithic algal communities in rivers of the Kolyma mountains, NE Siberia, Russia. Nova Hedwigia, 63, 309-334.

Potapova M.G. \& Charles D.F. 2002. - Benthic diatoms in USA rivers: distributions along spatial and environmental gradients. $J$. Biogeogr., 29, 167-187.

Potapova M.G. \& Charles D.F. 2003. - Distribution of benthic diatoms in U.S. rivers in relation to conductivity and ionic composition. Freshwat. Biol., 48, 1311-1328.

Puig M.A., Armengol J., González G., Peñuelas J., Sabater S. \& Sabater F. 1987. - Chemical and biological changes in the River Ter induced by a series of reservoirs. Pages 373-382 in Advances in Regulated Stream Ecology. Craig J.F. \& Kemper J.B. (eds.). Plenum Press, New York.

Rakowska B. 2004. - Benthic diatoms in polluted river sections of central Poland. Oceanol. Hydrobiol. Stud., 33, 11-21.

Robinson C.T., Rushforth S.R. \& Minshall G.W. 1994. - Diatom assemblages of streams influenced by wildfire. J. Phycol., 30, 209-216.

Rott E. 1995. - Diatoms of the Grand River, Ontario, Canada restudied after 25 years. Limnologica, 25, 165-192.

Rott E., Duthie H.C. \& Pipp E. 1998. - Monitoring organic pollution and eutrophication in the Grand River, Ontario, by means of diatoms. Can. J. Fish. Aquat. Sci., 55, 1443-1453.

Round F.E. 1981. - The Ecology of Algae. Cambridge University Press, Cambridge, $653 \mathrm{p}$.

Sabater S., Sabater F. \& Tomas X. 1987. - Water quality and diatom communities in two Catalan rivers (N.E. Spain). Wat. Res., 21, 901-911.

Sabater S. \& Sabater F. 1988. - Diatom assemblages in the River Ter. Arch. Hydrobiol., 111, 397-408.

Sabater S. \& Roca J.R. 1992. - Ecological and biogeographical aspects of diatom distribution in Pyrenean springs. Br. Phycol. J., 27, 203-213.

Sabater S. \& Admiraal W. 2005. - Biofilms as biological indicators in managed aquatic ecosystems. Pages 159-177 in Periphyton: Ecology, Exploitation and Management. Azim M.E., Verdegem M.C.J., van Dam A.A. \& Beveridge M.C.M. (eds.). CAB International, Wallingford, UK.

Soininen J. 2002. - Responses of ephilithic diatom communities to environmental gradients in some Finnish rivers. Internat. Rev. Hydrobiol., 87, 11-24.

Soininen J., Paavola R. \& Muotka T. 2004. - Benthic diatom communities in boreal streams: community structure in relation to environmental and spatial gradients. Ecography, 27, 330-342.

Steinman A.D., Mulholland P.J. \& Hill W.R. 1992. - Functional responses associated with growth form in stream algae. J. N. Am. Benthol. Soc., 11, 229-243.

Stevenson R.J. \& Pan Y. 1999. - Assessing environmental conditions in rivers and streams using diatoms. Pages 11-40 in The Diatoms: Application for the Environmental and Earth Sciences. Stoermer E.F. \& Smol J.P. (eds.). Cambridge University Press, Cambridge. 
Stoermer E.F. \& Smol J.P. 1999. - The Diatoms: Application for the Environmental and Earth Sciences. Cambridge University Press, Cambridge, $469 \mathrm{p}$.

ter Braak C.J.F. \& S Smilauer P. 2002. - CANOCO Reference Manual and CanoDraw for Windows User's Guide: Software for Canonical Community Ordination, Version 4.5. Microcomputer Power, Ithaca, NY, $500 \mathrm{p}$.

Vidal H. \& Gentili R. 2000. - Evolution de la qualite d'un petit cours d'eau mediterraneen, la Bouillide, apres rehabilitation d'une station d'epuration. Pages 245-246 in Compte rendu du 18e colloque de l'Association des diatomistes de langue francaise (Cryptogamie Algol.). Ector L., Compère P., Vidal H., Semprini M. \& Gentili R. (eds.)

Winter J.G. \& Duthie H.C. 2000. - Epilithic diatoms as indicators of stream total $\mathrm{N}$ and total $\mathrm{P}$ concentration. J. N. Am. Benthol. Soc., 19, 32-49.

Zimmerman G.M., Goetz, H. \& Mielke, P.W. Jr. 1985. - Use of an improved statistical method for group comparisons to study effects of prairie fire. Ecology, 66, 606-611. 